\title{
The relationship between cellular adhesion and surface roughness in polystyrene modified by microwave plasma radiation
}

This article was published in the following Dove Press journal:

International Journal of Nanomedicine

30 March 201 I

Number of times this article has been viewed

\author{
Esmaeil Biazar ${ }^{\prime}$ \\ Majid Heidari ${ }^{2}$ \\ Azadeh Asefnezhad ${ }^{2}$ \\ Naser Montazeri ${ }^{1}$ \\ 'Department of Chemistry, Islamic \\ Azad University, Tonekabon \\ Branch, Mazandaran; ${ }^{2}$ Department \\ of Biomaterial Engineering, Faculty \\ of Biomedical Engineering, Science \\ and Research Branch, Islamic Azad \\ University, Tehran, Iran
}

Correspondence: Naser Montazeri Islamic Azad University, Tonekabon Branch, Mazandaran, Iran Tel $+9891|7| 80155$ $\mathrm{Fax}+981924274415$

Email montazer50@toniau.ac.ir
Background: Surface modification of medical polymers can improve biocompatibility. Pure polystyrene is hydrophobic and cannot provide a suitable environment for cell cultures. The conventional method for surface modification of polystyrene is treatment with plasma. In this study, conventional polystyrene was exposed to microwave plasma treatment with oxygen and argon gases for 30, 60, and 180 seconds.

Methods and results: Attenuated total reflection Fourier transform infrared spectra investigations of irradiated samples indicated clearly the presence of functional groups. Atomic force microscopic images of samples irradiated with inert and active gases indicated nanometric surface topography. Samples irradiated with oxygen plasma showed more roughness $(31 \mathrm{~nm})$ compared with those irradiated with inert plasma $(16 \mathrm{~nm})$ at 180 seconds. Surface roughness increased with increasing duration of exposure, which could be due to reduction of the contact angle of samples irradiated with oxygen plasma. Contact angle analysis showed reduction in samples irradiated with inert plasma. Samples irradiated with oxygen plasma showed a lower contact angle compared with those irradiated by argon plasma. Conclusion: Cellular investigations with unrestricted somatic stem cells showed better adhesion, cell growth, and proliferation for samples radiated by oxygen plasma with increasing duration of exposure than those of normal samples.

Keywords: surface topography, polystyrene, plasma treatment, argon, oxygen

\section{Introduction}

Control of surface properties is very important for good adhesion. Biomaterial wettability is an important factor in the surface modification of materials. Surface modification of hydrophobic polymer surfaces can be achieved by wet (acid, alkali), dry (plasma), and radiation treatments (ultraviolet radiation and laser). ${ }^{1-3}$ Nonthermal and low-pressure plasma has been used in a series of surface treatment applications. The majority of plasma-assisted technologies are based on low-pressure processes. ${ }^{4}$ Treatment of polymeric materials with plasma is frequently used to achieve surface modification, control chemical composition, and modify surface topography. Moreover, microwave discharges are routinely employed in the processing of materials to deposit films and coatings. ${ }^{5-7}$ Physical surface modification and its effects on wettability are an interesting field for surface engineers. It should be noted that there has been a lot of scientific work done on molecularly smooth or modeled 'simply rough' surfaces, ${ }^{8}$ but little work has been done on wettability and the spreading phenomena of real engineering surfaces. ${ }^{9}$ From a practical point of view, a simple methodology is needed to account for the influence of a heterogeneous rough surface on wetting and contact 
angle measurements. The first attempt at this was made by Wenzel, and his simple model was based on the assumption that rough surfaces extend the solid-liquid interface area in comparison with projected smooth surfaces. Plasma treatment is generally used for surface modification of polymers because the processes involved are solvent-free and dry, the consumption of chemicals is extremely low, and the need for sterilization of the products is eliminated. ${ }^{10}$ Moreover, these processes are precisely controllable. The surface can be treated homogeneously and the surface chemistry can be tailored for the required end use. ${ }^{11}$ The plasma method uses energetic neutral atoms, ions, and electrons, which act on a surface to change its physicochemical properties. The nature of the gas species used and the energy of the ions are important parameters affecting the properties of a polymer surface immersed in plasma.

Polystyrene is a polymer which is commonly used in biomedical applications and is generally hydrophobic in nature. Certain applications, such as cell culture discs, require a more hydrophilic surface but without alteration of the bulk properties of the polymer. Hence, surface modification of such polymers becomes important. ${ }^{11}$ In this study, we used unrestricted somatic stem cells (USSCs), first isolated from umbilical cord blood in 2003 by Jager et al who evaluated their differentiation capacity for transplantation. ${ }^{12}$ In 2004, Koghler et al also evaluated these cells for their ability to produce cytokines. USSCs are pluripotent and are considered to be rare cell populations in umbilical cord blood. USSCs have a high potential to proliferate and differentiate, and so are considered to be valuable in cell therapy. ${ }^{13}$ USSCs are CD45-negative, adherent, and HLA Class II-negative stem cells with a long telomerase. Moreover, these cells possess a unique cytokine profile and are associated with self-renewing factors. Unlike other cord blood-derived mesenchymal cells, which differentiate only into osteoblasts, chondrocytes, adipocytes, ${ }^{14}$ and neurons, ${ }^{13}$ USSCs have the potential to differentiate into osteoblasts, chondrocytes, blood cells, neurons, hepatocytes, and heart tissue in ex vivo conditions. ${ }^{13}$ These cells express a wide range of factors, including adherent cells, growth factors, and various cytokines, including stem cell factor, vascular endothelial growth factor, granulocyte-macrophage colony-stimulating factor, macrophage colony-stimulating factor, transforming growth factor- $1 \beta$, interleukin (IL)-6, granulocyte colony-stimulating factor, leukemia inhibitory factor, Flt3 ligand, thrombopoetin, hepatocyte growth factor, stromal cell-derived-1 $\alpha$, IL-15, IL-12, IL-8, and IL-1 $\beta .{ }^{14}$ In this work, we demonstrated the effect of plasma on the surface properties of polystyrene, using argon (inert) and oxygen (reactive) gases, and the influence of surface roughness on its wetting properties.

\section{Materials and methods}

We used a microwave plasma source to modify the surfaces of the polystyrene samples. Microwave sources can be operated at low pressures of $10^{-3}$ to $10^{-1}$ millibars, which reduce the risk of gas phase contamination during processing. Moreover, plasma properties can be controlled conveniently by adjusting the microwave power. We demonstrate the effect of microwave plasma on the surface property of polystyrene with argon (inert), and oxygen (active) at different times. Culture dishes (orange) with a diameter of $60 \mathrm{~mm}$, size $1 \times 1 \mathrm{~cm}$ well, were placed in ethanol solution for 24 hours to eliminate pollution. Samples were then placed in a plasma chamber and exposed to oxygen and argon gases for 30, 60, and 180 seconds. Samples irradiated for these times were investigated by structural analysis and microscopy. Plasma surface treatment was achieved in microwave-induced plasma, with surface waves at a power level of $100 \mathrm{~W}$. The experimental apparatus is shown in Figure 1.

\section{Attenuated total reflection Fourier transform infrared analysis}

The samples were studied before and after surface modification using an infrared spectrometer device (Thermo Nicolet, Nexus 870, Madison, WI). Samples were cleaned beforehand. The test was performed based on the frequency absorption of covalent bands.

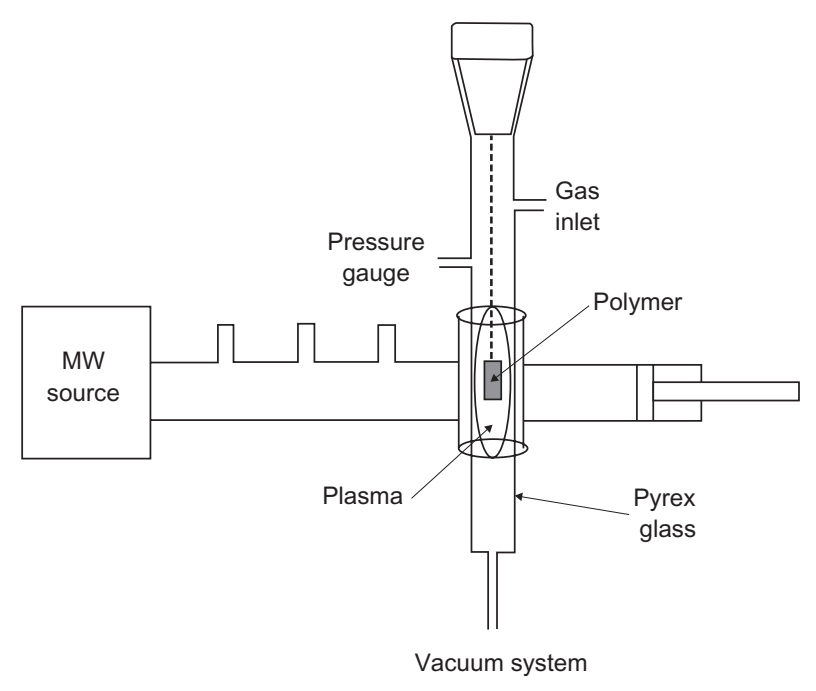

Figure I Experimental setup of microwave-plasma apparatus. 


\section{Atomic force microscopic analysis}

An atomic force microscope (Easyscan, Nanosurf Inc, Boston, MA) was used to study surface roughness resulting from treatment with plasma.

\section{Contact angle analysis}

The static contact angles of the sample surfaces were investigated by a contact angle measuring device (G10, Krüss, Matthews, NC) using the sessile drop method. The contact angle formed was defined as the angle between the solid/ liquid and liquid/vapor join surface.

\section{Cellular analysis}

\section{Culture and isolation of USSC from umbilical} cord blood

After receiving consent from the mothers (mean age 28 years), the infants' umbilical cords were obtained. Only $40 \%$ of the cord blood samples contained USSCs. After collecting the samples, the red blood cells were lysed using ammonium, and the isolation procedure was done using Ficoll. The samples were then rinsed twice with sterile phosphate-buffered saline (pH 7.4). After centrifugation, the cells were placed in Dulbecco's modified Eagle's medium (DMEM) with low glucose and enriched with $100 \mathrm{~nm}$ dexamethasone, $10 \%$ fetal bovine serum, and penicillin and streptomycin antibiotics. The first medium exchange process was done at 24 hours, and every four days thereafter. When $80 \%$ of the flask surface area was covered with cells, the cells were passaged using $0.25 \%$ trypsin and ethylenediamine tetra-acetic acid (ETDA). USSCs were regularly expanded on the culture medium, and $37^{\circ} \mathrm{C}$ temperature and $5 \% \mathrm{CO}_{2}$ were required for growth. The USSCs were first trypsinized and counted. The tubes containing $10^{5}-10^{6}$ cells were incubated on a rocker rotator for 6-10 hours, centrifuged at $1000 \mathrm{rpm}$ for six minutes, and 3\% human serum was then added for cell deposition. The mixture obtained was kept at room temperature for 30 minutes. The cells were again centrifuged, and phosphate-buffered saline was added to the cell deposit. The cell mixture was passed through a nylon mesh, and $100 \mu \mathrm{L}$ of cells was added to each tube with the following antibodies: anti-CD90, anti-CD105, anti-CD166, anti-CD45, anti-CD73, and anti-CD34. Thereafter, they were kept at $4^{\circ} \mathrm{C}$ out of light for 45 minutes. After washing, the cells were fixed in $100 \mu \mathrm{L}$ of $1 \%$ paraformaldehyde. Finally, flow cytometric analysis was carried out. Before and after coculture of mouse embryonic stem cells with USSC, karyotype analysis was performed on both cell types. The first and last passages were chosen for karyotype analysis. The cells were first placed in an incubator with $0.1 \mu \mathrm{g} / \mathrm{mL}$ colcemid for 3-4 hours. Next, they were trypsinized, and $0.075 \mathrm{M} \mathrm{KCl}$ solution was added. The cells were incubated with $5 \% \mathrm{CO}_{2}$ at $37^{\circ} \mathrm{C}$ for 20 minutes. In the next stage, methanol and acetic acid were added in a 1:3 ratio to fix the samples. Finally, the cells were mounted on slides and the chromosomes were subjected to karyotype analysis.

\section{Polymer surface cell cultures}

The samples and control were cleaned and autoclaved. Individual samples were placed in Petri dishes using a sterilized pincer. The USSC suspension was transferred to a flask $(25 \mathrm{~mL})$ containing $5 \mathrm{~mL}$ DMEM, $2 \mathrm{mM}$ glutamine, penicillin $100 \mu \mathrm{L} / \mathrm{mL}$, streptavidin $100 \mu \mathrm{L} / \mathrm{mL}$, and fetal bovine serum $10 \%$. The suspension was then placed in an incubator $(5 \%$ $\mathrm{CO}_{2}$ at $37^{\circ} \mathrm{C}$ ). The fibroblast cells were proliferated in the flask and were then washed using fetal bovine serum and EDTA. Trypsin and EDTA was added into the flask at $4^{\circ} \mathrm{C}$, and the flask was incubated for two minutes. Culture medium (fetal bovine serum and DMEM) was added to the flask and the cells were carefully pipetted. The cell suspension was transferred to a $15 \mathrm{~mL}$ Falcon tube and centrifuged at $1410 \mathrm{rpm}$ for five minutes. The solution was removed and the precipitate was transferred to a new flask $(75 \mathrm{~mL})$ for reculturing. Pieces of cell culture $(1 \times 1 \mathrm{~cm})$ from the Petri dish (control) and the main sample were placed individually in one of the Petri dish wells using a sterilized pincer. Thereafter, 100,000 cells/well were seeded into a 24 -well culture plate, removed by pipetting, and poured onto the control and main samples. All samples were then placed in a Memmert ${ }^{\circledR}$ incubator (Schwabach, Germany) at $37^{\circ} \mathrm{C}$ for 48 hours and studied using a Ceti microscope (Wolf Laboratories, Pocklington, York, UK). Cellular viability was determined by MTT assay. The MTT tetrazolium compound is reduced by living cells into a colored formazan product that is soluble in tissue culture medium. The quantity of formazan product is directly proportional to the number of viable cells in the culture. The assays were performed by adding $1 \mathrm{~mL}$ of MTT solution (Sigma, St Louis, $\mathrm{MO}$ ) and $9 \mathrm{~mL}$ of fresh medium to each well after aspirating the spent medium and incubation at $37^{\circ} \mathrm{C}$ for four hours in the dark. Colorimetric measurement of the formazan dye was performed at a wavelength of $606 \mathrm{~nm}$ using a Rayto microplate reader.

\section{Results \\ Attenuated total reflection Fourier transform infrared analysis}

Attenuated total reflection Fourier transform infrared analysis (ATR-FTIR) spectra results for normal and modified 
polystyrene samples treated with plasma irradiation (oxygen and argon gases) at different times are shown in Figure 2A. The ATR-FTIR spectra of polystyrene irradiated with argon plasma is shown in Figure 2B. There was no significant difference between normal samples and those irradiated with argon plasma. However, a significant difference was observed at $3400-3700 \mathrm{~cm}^{-1}$ that could be related to an $\mathrm{OH}$ group and demonstrated the effect of surface treatment in comparison with the normal sample. The ATR-FTIR spectra of polystyrene irradiated with oxygen plasma is shown in Figure $2 \mathrm{C}$. The spectrum observed at $1750 \mathrm{~cm}^{-1}$ could be related to the $\mathrm{C}=\mathrm{O}$ group, and showed successful surface modification with oxygen plasma. The tension peak at $1000-1300 \mathrm{~cm}^{-1}$ could be related to the $\mathrm{C}=\mathrm{O}$ group and a peak at $3000 \mathrm{~cm}^{-1}$ could be related to the $-\mathrm{CH}_{3}$ group. Moreover, the tension peak observed at $3400-3700 \mathrm{~cm}^{-1}$ could be related to an $\mathrm{OH}$ group that demonstrated the effect of surface treatment on the samples.

\section{Atomic force microscopic analysis}

The surface topology of the normal and polystyrene samples irradiated for different times and exposures (active and inert gases) were investigated using atomic force microscopy.
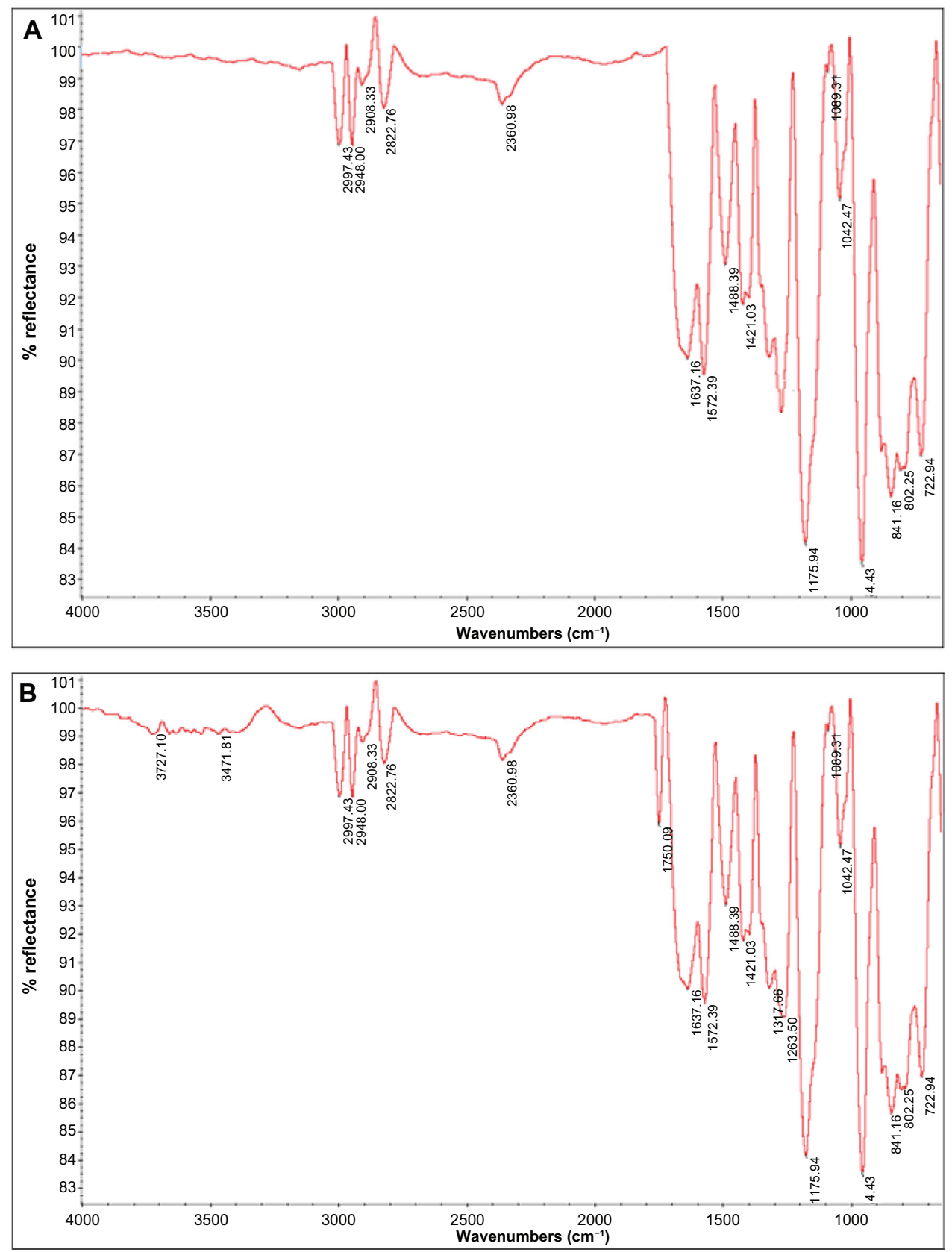

Figure 2 (Continued) 


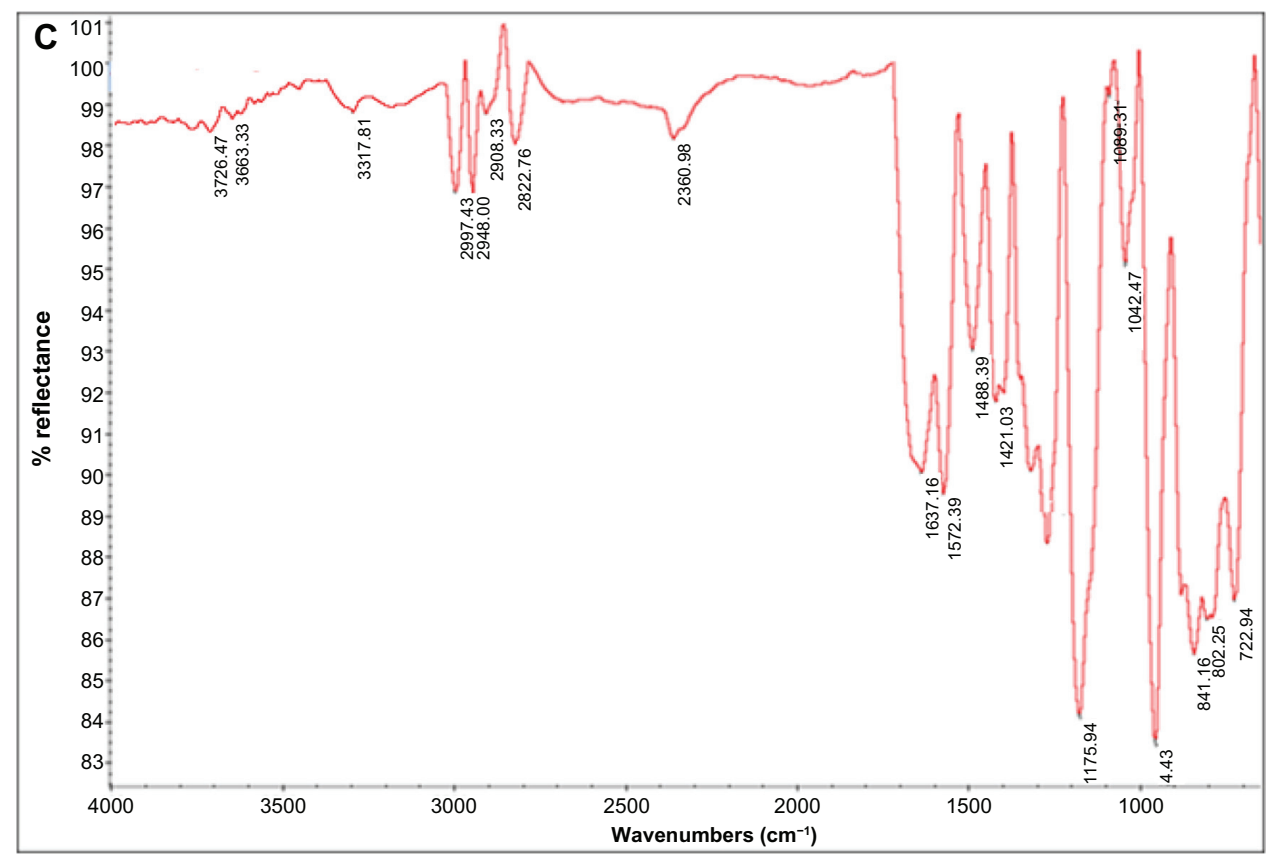

Figure 2 A) Attenuated total reflection Fourier transform infrared spectra for normal polystyrene, B) polystyrene irradiated by argon plasma, and C) polystyrene irradiated by oxygen plasma.

The three-dimensional topography of the normal samples is shown in Figure 3. In this figure, a smooth surface with little roughness can be observed. This roughness could be due to scratches resulting from cleaning of the samples.

Figure 4 shows the topography of the polystyrene modified with argon plasma at 30,60, and 180 seconds. A difference was observed between the topography of samples irradiated with argon plasma for different times compared with the normal samples. Surface roughness increased with increasing exposure, although little difference was observed in surface topography.

Figure 5 shows the topography of polystyrene modified by oxygen plasma at 30,60 , and 180 seconds. The topography of samples irradiated with oxygen plasma

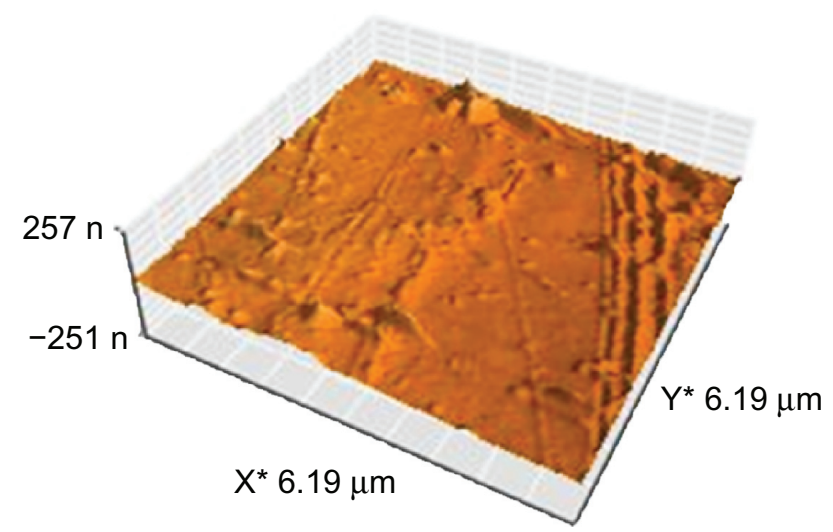

Figure 3 Topography of normal polystyrene. at different times differed from that of normal samples modified with argon plasma. Surface roughness increased with increasing duration of exposure. A lot of difference was observed in surface topology with increasing duration of exposure.

The surface roughness of the normal samples and samples irradiated with oxygen and argon plasma are shown in Table 1. The results show that the roughness of
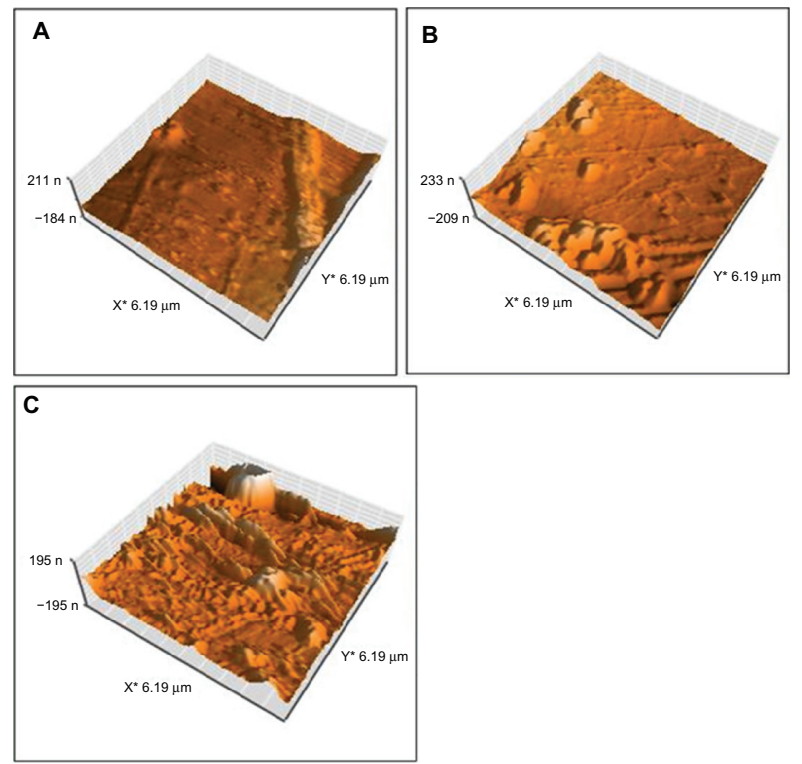

Figure 4 Topography of irradiated polystyrene by argon plasma at A) 30 seconds, B) 60 seconds, and C) 180 seconds. 


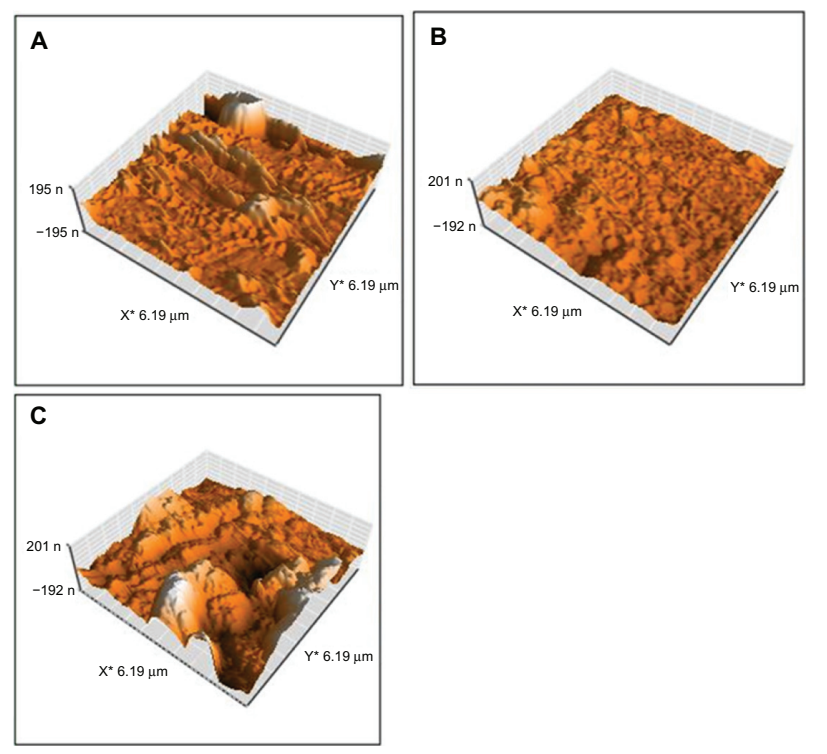

Figure 5 Topography of irradiated polystyrene by oxygen plasma at A) 30 seconds, B) 60 seconds, and C) 180 seconds.

the samples modified with oxygen plasma was higher in comparison with samples modified with argon plasma. Samples irradiated with oxygen plasma should double the surface roughness $(31 \mathrm{~nm})$ seen for inert plasma $(16 \mathrm{~nm})$ at 180 seconds.

\section{Contact angle analysis}

Table 2 shows the angles obtained for normal samples and those modified with oxygen and argon plasma and at different durations of exposure. The results showed that samples modified using either gas reduced the contact angle. Samples modified with oxygen plasma showed a higher level of contact angle reduction in comparison with the sample modified with argon plasma, indicating that the sample modified with oxygen plasma was more hydrophilic than the normal sample.

\section{Cell results}

USSCs isolated from cord blood were cultured during 50 passages. USSCs have a high proliferation capacity because they need to repeat passages. The proliferation and

Table I Surface roughness of normal and irradiated samples

\begin{tabular}{llll}
\hline $\begin{array}{l}\text { Sample } \\
\text { (seconds) }\end{array}$ & $\begin{array}{l}\text { Surface roughness } \\
\text { of polystyrene } \\
\text { treated by argon } \\
\text { plasma (nm) }\end{array}$ & $\begin{array}{l}\text { Sample } \\
\text { (seconds) }\end{array}$ & $\begin{array}{l}\text { Surface roughness } \\
\text { of polystyrene } \\
\text { treated with oxygen } \\
\text { plasma (nm) }\end{array}$ \\
\hline Normal & 7.37 & Normal & 7.37 \\
30 & 8.21 & 30 & 12.67 \\
60 & 12.14 & 60 & 26.41 \\
\hline
\end{tabular}

Table 2 Contact angles of normal and irradiated samples

\begin{tabular}{llll}
\hline $\begin{array}{l}\text { Sample } \\
\text { (seconds) }\end{array}$ & $\begin{array}{l}\boldsymbol{\theta} \text { (degrees) } \\
\text { (treated by } \\
\text { argon plasma) }\end{array}$ & Sample & $\begin{array}{l}\boldsymbol{\theta} \text { (degrees) } \\
\text { (treated } \\
\text { by oxygen } \\
\text { plasma) }\end{array}$ \\
\hline Normal & 90.1 & Normal & 90.1 \\
30 & 58.5 & 30 & 46.6 \\
60 & 53.7 & 60 & 43.7 \\
180 & 44.2 & 180 & 37.1 \\
\hline
\end{tabular}

morphology of these cells were very similar to each other before and after freezing. No indication of viral or mycoplasma infection was observed during the different stages of work on USSCs. USSCs are morphologically adherent spindle-shaped cells with a size of 20-25 $\mu \mathrm{m}$ (Figure 6). After three passages, flow cytometric analysis was performed on the USSCs in order to express stem cell markers. The markers were as follows: CD34, CD45, CD73, CD105, CD90, and CD166 (Figure 7). For USSCs, the expression of surface markers, such as CD90, CD105, CD166, and CD73 were positive, but CD34 and CD45 were negative.

\section{Cell study}

Table 3 shows the MTT assays for control, normal, and polystyrene films irradiated with plasma (oxygen and argon gases) at 30,60, and 180 seconds. The results show high viability of samples irradiated with plasma at different times, ie, 61\% with argon plasma for 30 seconds, 65\% with argon plasma for 60 seconds, $121 \%$ with argon plasma for 180 seconds, $81 \%$ with oxygen plasma for 30 seconds, $91 \%$ with oxygen plasma for 60 seconds, and $31 \%$ with oxygen plasma for 180 seconds. In addition, the films irradiated with plasma for longer durations showed better viability. Samples

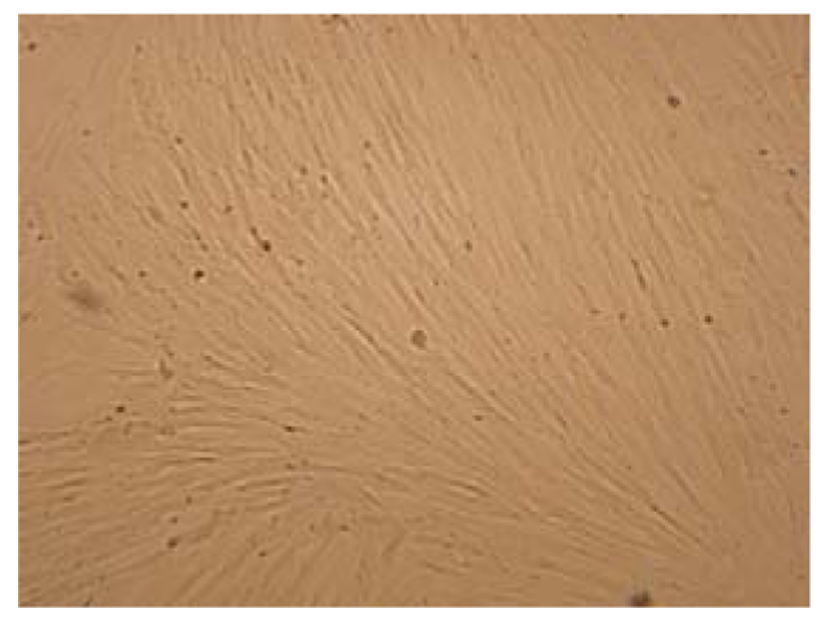

Figure 6 Morphology of unrestricted somatic stem cells: Spindle-shaped cells sized 20-25 $\mu \mathrm{m}$. 

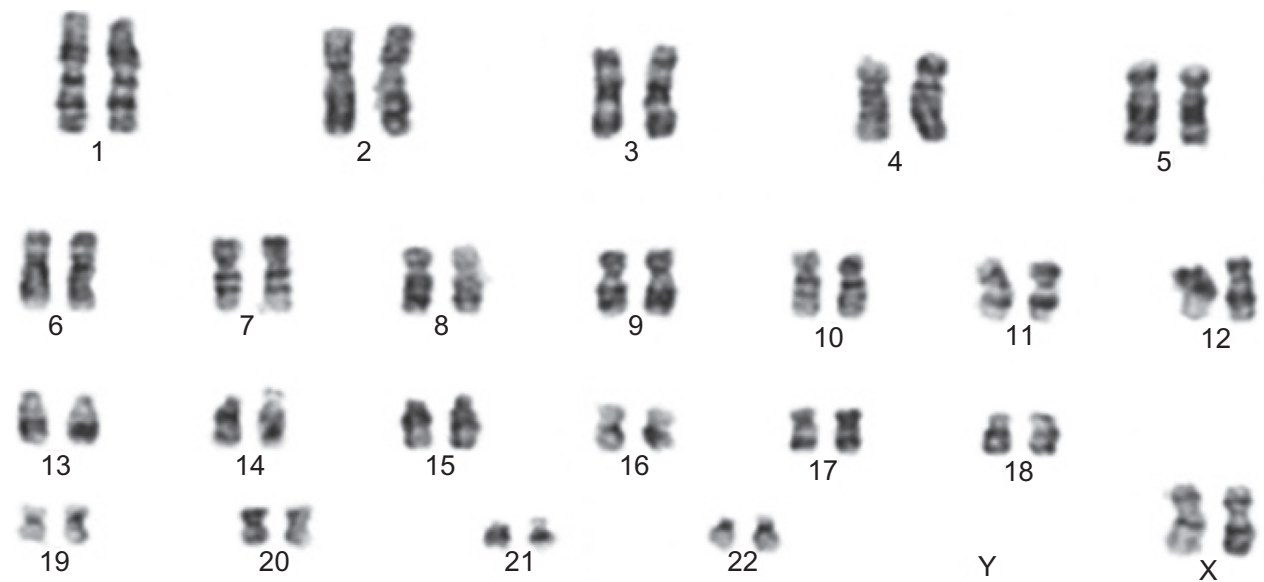

Figure 7 Markers of flow cytometric analysis performed on unrestricted somatic stem cells. Before beginning the experiments, karyotype analysis was performed on unrestricted somatic stem cells of passage 2, revealing a normal $44, \mathrm{XX}$ karyotype. After 48 passages, these cells were subjected to karyotype analysis once again, and they were shown to have a normal chromosome karyotype of $44, \mathrm{XX}$ (see Figure 8).

irradiated with plasma for 180 seconds also showed more proliferation of cells. Figure 9 shows cell culture images on the normal and irradiated films, as well as those for control samples. The cellular images showed good growth on irradiated films, especially those irradiated with active gases for longer durations.

\section{Discussion}

In this study, the surface modification and topography of normal polystyrene and polystyrene irradiated with oxygen plasma and argon plasma for three periods of time were investigated. Microwave plasma has a significant advantage over other techniques, ie, radiofrequency glow discharge, and is frequently used in polymer surface modifications. ${ }^{15}$ ATR-FTIR analysis of the samples modified with these gases demonstrated the existence of functional groups, including $\mathrm{C}=\mathrm{O}, \mathrm{CO}$, and $\mathrm{OH}$. Atomic force microscopic images showed much surface roughness on the samples modified by oxygen plasma in comparison with normal samples and those modified with argon plasma. Contact angle analysis showed
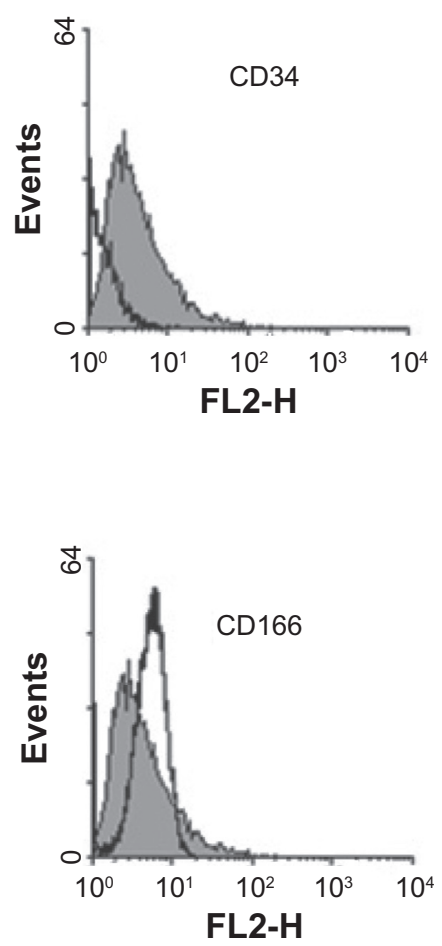
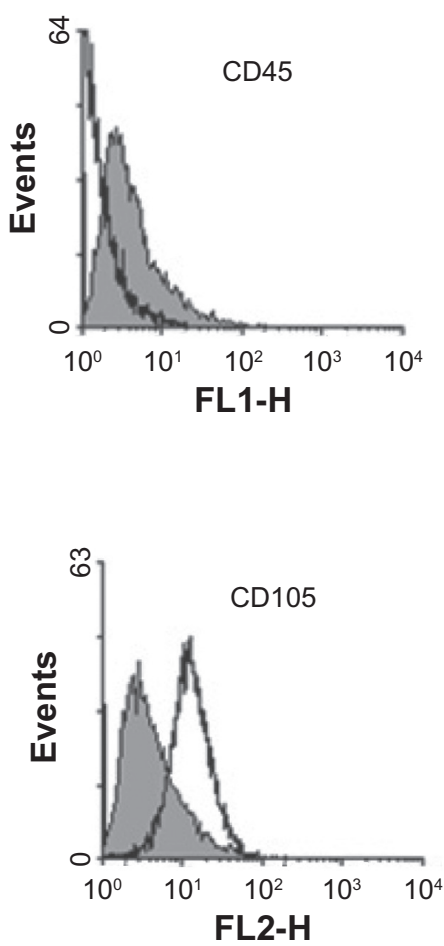
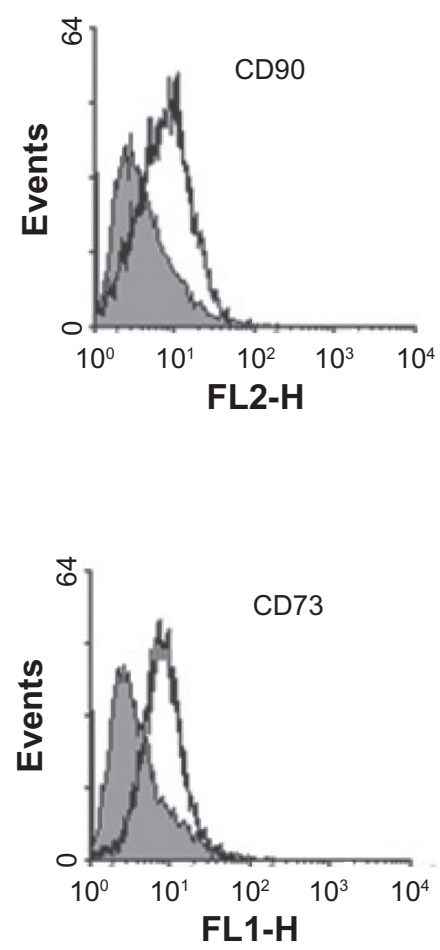

Figure $\mathbf{8}$ Chromosome karyotype analysis performed on unrestricted somatic stem cells. 
Table 3 MTT analysis of the samples

\begin{tabular}{llll}
\hline Sample & $\begin{array}{l}\text { Cell viability (treated by argon } \\
\text { plasma), \% }\end{array}$ & Sample & $\begin{array}{l}\text { Cell viability (treated by oxygen } \\
\text { plasma), \% }\end{array}$ \\
\hline Normal & 53 & Normal & 53 \\
Control & 100 & Control & 100 \\
30 & 61 & 30 & 81 \\
60 & 65 & 60 & 91 \\
180 & 121 & 180 & 131 \\
\hline
\end{tabular}
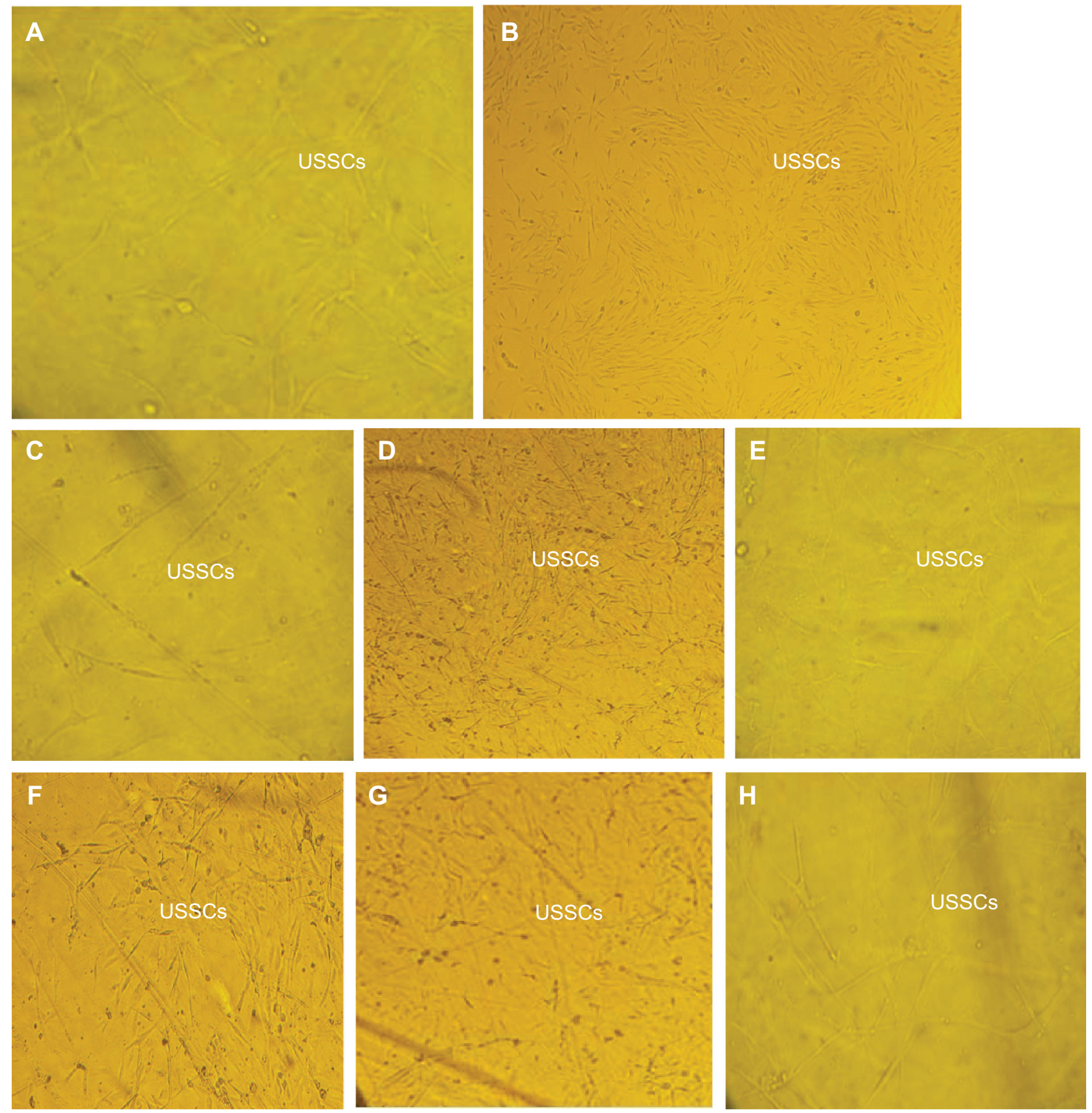

Figure 9 Unrestricted somatic stem cell culture on A) normal (untreated polystyrene), B) control surfaces, C) polystyrene treated with argon plasma for 30 seconds, D) polystyrene treated with argon plasma for 60 seconds, E) polystyrene treated with argon plasma for 180 seconds, F) polystyrene treated with oxygen plasma for 30 seconds, $\mathbf{G})$ polystyrene treated with oxygen plasma for 60 seconds, and $\mathbf{H}$ ) polystyrene treated with oxygen plasma for 180 seconds. 
further contact angle reduction for samples modified with oxygen plasma in comparison with samples modified using argon plasma. These differences could be related to physical modification or doubled roughness of samples modified by oxygen plasma in comparison with samples modified using argon plasma. Cellular investigations using USSCs showed better adhesion, growth, and viability of films radiated with either plasma, especially oxygen plasma, than did normal films. These irradiated films could be used as substrates for cellular culture.

\section{Disclosure}

The authors report no conflicts of interest in this work.

\section{References}

1. Lu HW, Lu QH, Chen WT, et al. Cell culturing on nanogrooved polystyrene Petri dish induced by ultraviolet laser irradiation. Mater Lett. 2004;58:29-32.

2. Roucoules G, Mathia T, Lanteri P. Hydrophobic mechanochemical treatment of metallic surfaces. Wettability measurements as means of assessing homogeneity. Adv Colloid Interface Sci. 2002;97:177-201.

3. Hay KM, Dragila MI, Liburdy J. Theoretical model for the wetting of a rough surface. J Colloid Interface Sci. 2008;325:472-477.

4. Kogelschatz U. Dielectric-barrier discharges: Their history, discharge physics and industrial applications. Plasma Chem Plasma Proc. 2003;23:1-46.
5. Kuzmichev AI. Ion plasma sources based on a microwave oven. Instrum Exp Tech. 1994;37:648-653.

6. Asmussen V. Electron cyclotron resonance microwave discharge for etching and thin film deposition. J Vac Sci Technol. 1989;7:883-889.

7. Takahashi C, Jin Y, Nishimura K, Matsuo S. Anisotropic etching of $\mathrm{Si}$ and WSiN using ECR plasma of SF6-CF4 gas mixture. Jpn J Appl Phys. 2000;39:3672-3676.

8. Prabhu KN, Fernandes P, Kumar G. Effect of surface roughness on wetting characteristics of vegetable oils. Mater Design. 2009;30: 297-305.

9. Kubiak KJ, Mathia TG, Wilson MCT. Methodology for metrology of wettability versus roughness of engineering surfaces. Proceedings of Fourteenth International Congress of Metrology. Paris, France, June 22-25, 2009.

10. Wenzel RN. Resistance of solid surfaces to wetting by water. Ind Eng Chem. 1936;28:988-994.

11. Chan CM, Ko TM, Hiraoka H. Polymer surface modification by plasmas and photons. Surf Sci Rep. 1996;24:1.

12. Jager M, Sager M, Knipper A, et al. In vivo and in vitro bone regeneration from cord blood derived mesenchymal stem cells. Der Orthopäde. 2004; 33:1361-1372. German.

13. Kogler G, Sensken S, Airey JA, et al. A new human somatic stem cell from placental cord blood with intrinsic pluripotent differentiation potential. J Exp Med. 2004;200:123-135.

14. Kogler G, Radke T, Lefort A, et al. Cytokine production and hematopoiesis supporting activity of cord blood-derived unrestricted somatic stem cells. Exp Hematol. 2005;33:573-583.

15. Nowak S, Gröning P, Küttel OM, Collaud M, Dietler G. Electron cyclotron resonance plasma experiment for in situ surface modification, deposition, and analysis. J Vac Sci Technol. 1992;10:3419-3425.
International Journal of Nanomedicine

\section{Publish your work in this journal}

The International Journal of Nanomedicine is an international, peerreviewed journal focusing on the application of nanotechnology in diagnostics, therapeutics, and drug delivery systems throughout the biomedical field. This journal is indexed on PubMed Central, MedLine, CAS, SciSearch ${ }^{\circledR}$, Current Contents ${ }^{\circledR} /$ Clinical Medicine,

\section{Dovepress}

Journal Citation Reports/Science Edition, EMBase, Scopus and the Elsevier Bibliographic databases. The manuscript management system is completely online and includes a very quick and fair peer-review system, which is all easy to use. Visit http://www.dovepress.com/ testimonials.php to read real quotes from published authors. 